\title{
Early Cenozoic Multiple Thrust in the Tibetan Plateau
}

\author{
Zhenhan Wu, ${ }^{1}$ Peisheng Ye, ${ }^{2}$ Patrick J. Barosh, ${ }^{3}$ Daogong Hu, ${ }^{2}$ and Lu Lu ${ }^{1}$ \\ ${ }^{1}$ Chinese Academy of Geological Sciences, Beijing 100037, China \\ ${ }^{2}$ Institute of Geomechanics, Chinese Academy of Geological Sciences, Beijing 100081, China \\ ${ }^{3}$ P. J. Barosh and Associates, 103 Aaron Avenue, Bristol, RI 02809, USA
}

Correspondence should be addressed to Zhenhan Wu; wuzhenhan@yahoo.com.cn

Received 11 March 2012; Revised 3 June 2012; Accepted 8 November 2012

Academic Editor: Keiko Hattori

Copyright (C) 2013 Zhenhan Wu et al. This is an open access article distributed under the Creative Commons Attribution License, which permits unrestricted use, distribution, and reproduction in any medium, provided the original work is properly cited.

\begin{abstract}
Recently completed regional geological mapping at a scale of $1: 250,000$ or larger across all of the Tibetan Plateau coupled with deep seismic surveys reveals for the first time a comprehensive depiction of the major early Cenozoic thrust systems resulting from the northward subduction of the Indian Continental Plate. These systems define a series of overlapping north-dipping thrust sheets that thickened the Tibetan crust and lead to the rise of the plateau. The few south-dipping thrusts present apparently developed within a sheet when the back moved faster than the toe. Many of the thrusts are shown to extend to the middle-lower crustal depths by seismic data. The regional thrust systems are the Main Central, Renbu-Zedong, Gangdese, Central Gangdese, North Gangdese, Bangoin-Nujiang, Qiangtang, Hohxil, and South Kunlun Thrusts. The minimal southward displacements of the South Kunlun, Hohxil, South Qiangtang, and Central Gangdese Thrusts are estimated to be $30 \mathrm{~km}, 25 \mathrm{~km}, 150 \mathrm{~km}$ and $50 \mathrm{~km}$, respectively. Deep thrusting began in the Himalaya-Tibetan region soon after India-Eurasia continental collision and led to crustal thickening and subsequent uplift of the Tibetan Plateau during Late Eocene-Early Miocene when the systems were mainly active. The major thrust systems ceased moving in Early Miocene and many were soon covered by lacustrine strata. This activity succeeded in the late Cenozoic to crustal extension and strike-slip movement in the central Tibetan Plateau. The revelation of the full array of the early Cenozoic thrust systems provides a much more complete understanding of the tectonic framework of the Tibetan Plateau.
\end{abstract}

\section{Introduction}

A great change in landforms and environments took place during the Cenozoic era as the Indian Continental Plate was subducted northward beneath central Asia to cause crustal thickening and uplift of the Tibetan Plateau. The Tethys Ocean had occupied the Himalayan and southern Tibetan areas at a time when volcanic rocks of the Linzizong Group formed in the Paleocene-Early Eocene magmatic belt along the Gangdese island arc, while the oceanic plate plunged northward along the Yarlung Zangbo suture $[1,2]$. Continental red-beds of Fenghuoshan Group were being deposited farther north in central and northern Tibet in Late Cretaceous-Early Cenozoic, and a sea existed beyond Tibet in southwestern Tarim basin [3] (Figure 1). The subduction of the oceanic plate, volcanic eruptions, and intrusions, which ended before $\sim 45 \mathrm{Ma}$, was followed by the subduction of the
Indian Continental Plate [4] and the subsequent contractional deformation and crustal shortening across the Tibetan Plateau [5]. A variety of hypotheses have been proposed to explain the tectonic process [6-9], but many unanswered questions remained due to the lack of regional data on Cenozoic stratigraphy and structure and tectonic movements as well as a limited understanding of the deep structure of the Tibetan Plateau. There also has been in debate as to which direction various thrust zones dip and if different dips mean different episodes of thrusting. The newly completed regional geologic mapping and seismic surveys across the plateau now provide critical information relevant to these questions.

Much of what has been described in the past about the Tibetan Plateau was primarily based on road traverses, such as the $1: 500,000$ scale geological mapping along GolmudLhasa Highway during the Chinese-British collaboration in mid 1980s [25]. Now, however, regional mapping has been 

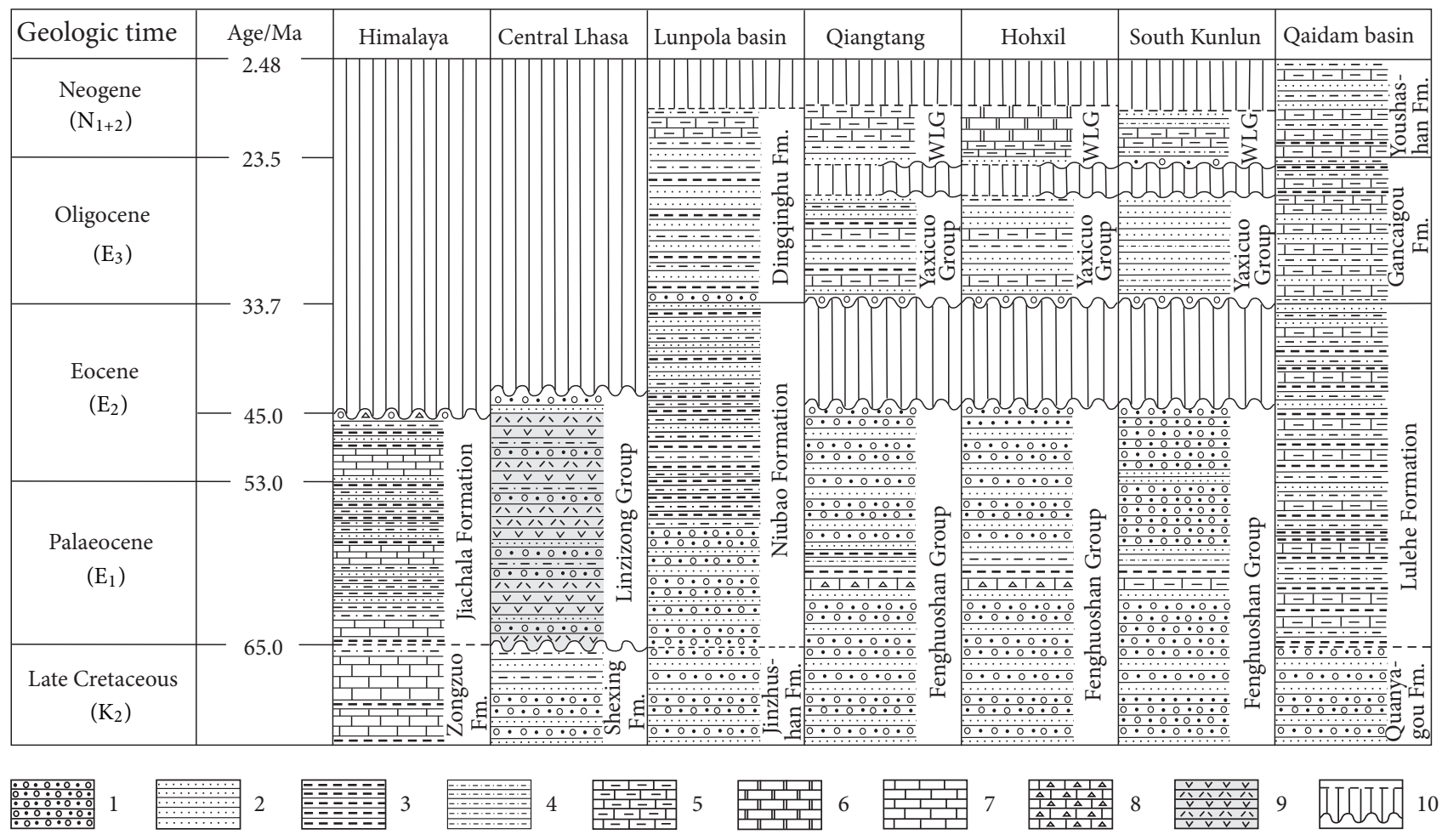

Figure 1: Tertiary stratigraphic systems in the Tibetan Plateau. Explanation: 1: conglomerate and sandstone; 2: sandstone; 3: shale; 4: mudstone and muddy siltstone; 5: marl; 6: dolomite and dolomitic limestone; 7: limestone; 8: breccia limestone; 9: Island-arc-type volcanic rocks; 10: unconformity; WLG: Wudaoliang Group [10]. The Zongzuo and Jiachala Formations are dominated by marine deposits [1], and the other Formations are terrestrial deposits. Geological time scale is that recommended by China National Committee of Stratigraphy (2002).

completed across the region by Chinese geologists after decades of working, and the understanding of the geology keeps improving as the field work progresses. These maps include the following: the $1: 1,000,000$ scale geological map of southern and central Tibetan Plateau [26], 1:200,000 scale geological maps of northeastern Tibetan Plateau [27], and $1: 200,000$ scale geological maps of eastern Tibetan Plateau $[28,29]$. The China Geological Survey also carried out $1: 250,000$ scale geological mapping throughout the Tibetan Plateau since $2000[30,31]$, and released $1: 250,000$ scale geological maps of the southern, central, and northern plateau in 2002-2007 and revised the earlier $1: 250,000$ scale geological maps of eastern Tibet. The authors finished a $1: 250,000$ scale geological map of the Damxung quadrangle in the central Lhasa Block [32] and 1:100,000 scale structural maps of the central Qiangtang Block [19] and portions of the East Kunlun Mountains. This was augmented in complex areas by detailed $1: 50,000$ and $1: 25,000$ scale geological mapping in the southern East Kunlun Mountains [11, 33, 34]. All of this mapping, especially since 2000 , has provided new information on the stratigraphy and structures that sheds considerable insight on the Cenozoic tectonic movements of the region [30].

From the $1: 250,000$ scale geological maps, field studies of typical thrust fault from the Kunlun to Himalaya Mountains, and previous studies we compiled selected data on early Cenozoic strata, structures, plutons, and volcanic rocks to produce a Late Eocene-Oligocene paleotectonic map of the Tibetan Plateau (Figure 2). We also identified deep thrusts within the middle-lower crust from seismic reflection profiles and wide-angle seismic data to tie into the surface structures. The results reveal the principal structural systems and deep structures that yield a greatly improved comprehension of the geodynamic movements, which caused the crustal thickening and uplift of the Tibetan Plateau.

This paper shows both previously known thrust systems and newly discovered ones to present for the first time a comprehensive depiction of thrust zones due to early Cenozoic compression. The areas that were theoretically predicted are now thoroughly understood through geologic and seismic data. This research also demonstrates that a single essentially north-dipping series of thrust sheets forms the Tibetan Plateau, although the related deep processes may be very complex. The purpose of this paper is to present a brief outline of the stratigraphy and descriptions of the major early Cenozoic thrust systems and the derived crustal structures across the entire Himalayan-Tibetan Plateau region.

\section{Stratigraphic Systems}

The stratigraphy is of particular importance in recognizing the dislocations and offsets across thrust systems. The early Cenozoic strata, which reflect the contrasting environments 


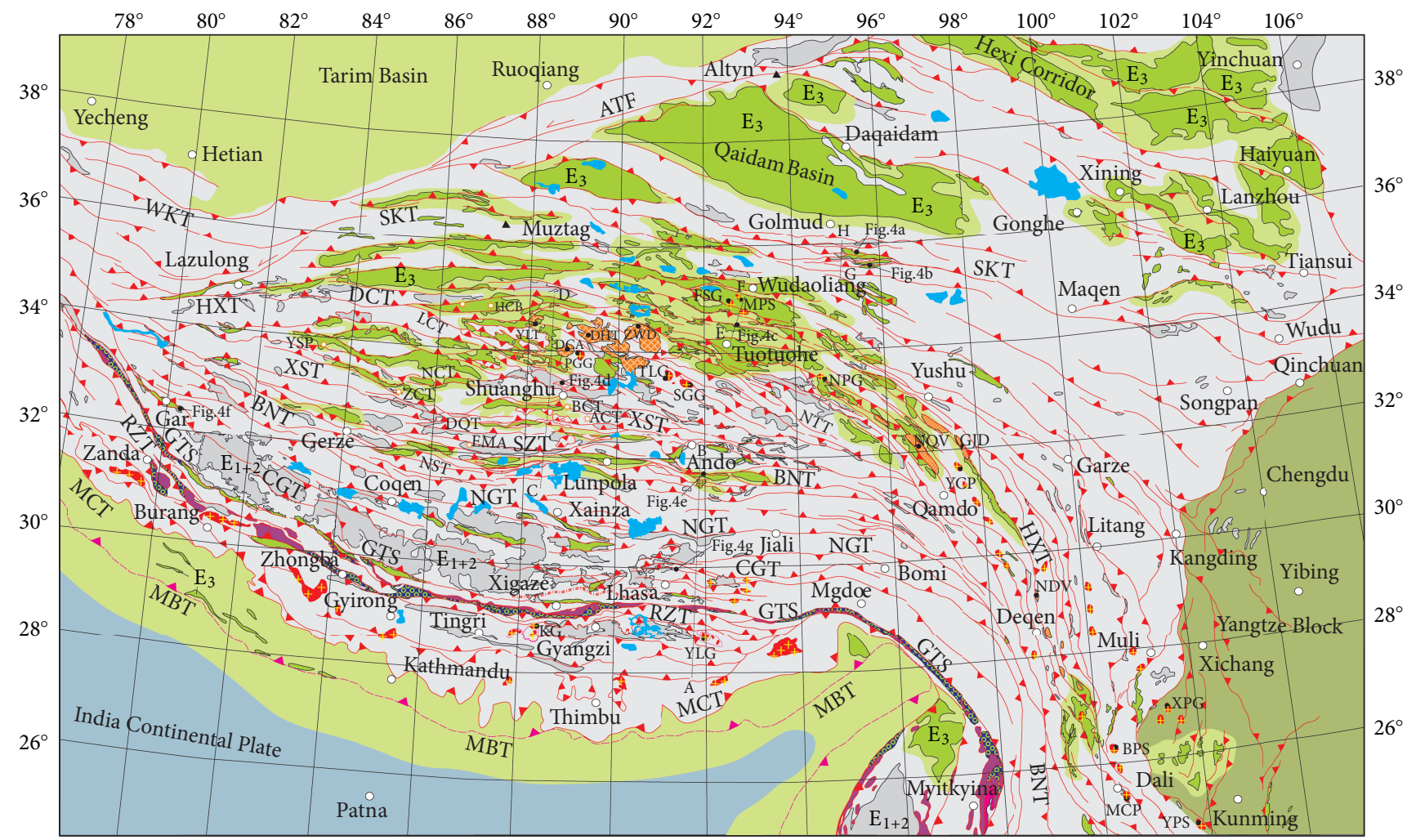

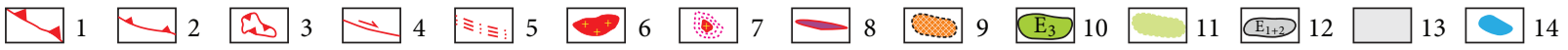

FIgURE 2: Paleotectonic map of the Tibetan Plateau for the Late Eocene-Oligocene. Explanation: 1: major thrust fault; 2: thrust fault; 3: nappe or outlier; 4: strike-slip fault; 5: ductile shear zone; 6: Late Eocene-Oligocene granite; 7: granitic dome; 8: ophiolite along the Yarlung Zangbo Suture (YZS); 9: Late Eocene-Oligocene volcanic rocks; 10: Oligocene $\left(\mathrm{E}_{3}\right)$ terrestrial strata; 11: Oligocene basin; 12: Paleocene-Eocene $\left(\mathrm{E}_{1+2}\right)$ strata; 13: erosion area; 14: present-day lake. Major fault systems: ATF: Altyn Tagh Fault [5, 8]; WKT: West Kunlun Thrust; SKT: South Kunlun Thrust [11]; HXT: Hohxil Thrust; NTT: North Tangula Thrust [12], DCT: Dogai Coren Thrust; LCT: Longwei Co Thrust; NCT: north central Thrust; XST: Xiaocaka-Shuanghu Thrust; DQT: Doma-Qixiang Co Thrust; SZT: Saibu Co-Zagya Thrust; NST: Nima-Silin Co Thrust; BNT: Bangoin-Nujiang Thrust; NGT: North Gangdese Thrust; CGT: Central Gangdese Thrust; GTS: Gangdese Thrust System [13]; RZT: RenbuZedong Thrust [13, 14]; MCT: Main Central Thrust [15, 16]; MBT: Main Boundary Thrust after Mid Miocene [5]. Black dots mark sampling location for isotopic ages and outcrops for photos, and dotted lines A-B, C-D, E-F, and G-H mark positions of regional cross sections.

of deposition across the region, provide important information related to the structural control of sedimentation. Paleocene-Eocene marine strata were being deposited in the northern Himalaya belt [1], while Paleocene-Early Eocene volcanic-sedimentary rocks of the Linzizong Group accumulated in the Gangdese Magmatic Arc and early Cenozoic continental stratigraphic units were laid down in the northern Lhasa, Qiangtang, Hohxil, and Kunlun-Qaidam Blocks [30]. Farther north marine strata were accumulating in the southwestern Tarim basin about the same time [35]. The unconformities that reflect uplift also are strikingly different between these areas.

The Paleocene to early Eocene strata in the Himalaya Block consists of marine dolomite, dolomitic limestone, and shale of the Jiachala Formation that sits conformably on Late Cretaceous limestone [1,2]. This is in sharp contrast with the volcanic rocks in the northern Gangdese Magmatic Arc in the central Lhasa Block to the north. There the section includes Early Eocene rhyolite, trachyte, conglomerate and mudstone of the Pana Formation, Late Paleocene rhyolite, andesite, conglomerate and sandstone of the Nianbo Formation, Early Paleocene andesite, dacite, basalt-andesite breccia and conglomerate of the Dianzhong Formation, and Paleocene volcanic rocks and conglomerate of the Meisu Formation [30]. These units lie with an angular unconformity over Late Cretaceous shale, sandstone, and conglomerate of the Shexing Formation (Figure 1).

The Paleocene-Eocene lacustrine, fluvial and alluvial deposits formed to the north in continental basins of the central and northern Tibetan areas [30,36]. These constitute the Paleocene-Eocene marl, shale, sandstone, and mudstone of the Lulehe Formation in the Qaidam Basin, Late Cretaceous-Eocene reddish conglomerate and sandstone of the Fenghuoshan Group in the Qiangtang and Hohxil Blocks, and Paleocene-Eocene conglomerate, sandstone, marl, and mudstone of Niubao Formation unconformably overlying 
Late Cretaceous red-beds of the Jingzhushan Formation, which is dominated by conglomerate and sandstone in Lunpola Basin (Figure 1). Oligocene lacustrine mudstone, marl, and sandstone that intercalated with gypsum of the Dingqinghu Formation, Yaxicuo Group, and Gancaigou Formation covered the Niubao Formation, Fenghuoshan Group, and Lulehe Formation in the Lunpola, Hohxil, and Qaidam Basins, respectively (Figure 1). The ages of the early Tertiary continental strata are constrained by sporopollenin assemblages [10] and magnetostratigraphic data [36, 37].

Farther north in the southwest Tarim basin a marine sequence of Paleocene to basal Oligocene marine shale, siltstone, limestone, marl, and intercalated thick gypsum of the Kashi Group is unconformably covered by Late OligoceneMiocene lacustrine sandstone, siltstone, marl, and minor shale of the Wuqia Group [3]. This sequence rests on the Late Cretaceous radiolarian limestone and shale of the Yingjisha Group [35].

\section{Large Thrust Systems in the Upper Crust}

The early Cenozoic stratigraphic sequences are now disrupted and telescoped by intensive thrusting in the Himalayan Mountains and Tibetan Plateau as a result of the India-Eurasia continental collision. The thrusts form several major systems, each of which contains several thrusts that extend over the entire region, and thrust faults constitute the early Cenozoic structural framework of Tibet (Figure 2). These thrust systems, from south to north are the Main Central Thrust (MCT) $[6,15]$, Renbu-Zedong Thrust (RZT) and Gangdese Thrust system (GTS) in southern Tibet [13], the Central Gangdese Thrust (CGT), North Gangdese Thrust (NGT) and Bangoin-Nujiang Thrust (BNT) in central Tibet, and the Qiangtang Thrust system (QTS), Hohxil Thrust (HXT), and South Kunlun Thrust (SKT) [11] in northern Tibet. Most thrust faults of the CGT, NGT, BNT, QTS, HXT, and SKT are the ones newly discovered by mapping since 2000 . The West Kunlun Thrust (WKT) [38] in northwestern Tibetan Plateau and the North Qaidam, South Qilian, Central Qilian, and North Qilian Thrust systems in northeastern Tibetan Plateau $[5,39]$ may have been activated in early Cenozoic, but their main movement occurred in late Cenozoic [8]. The thrust systems provide boundaries of the regional structural blocks as well as internal breaks. The chief systems and the strata displaced are briefly summarized below from south to north.

3.1. Main Central Thrust. The Main Central Thrust (MCT) and associated thrusts in combination with the Main Boundary Thrust (MBT) form a complex zone whose movement lifted the Himalayan Mountains [5, 6, 40]. Proterozoic and Early Paleozoic metamorphic rocks are thrust southward over Late Paleozoic strata to form large-scale nappes of gneiss, ductile shear zones and tight folds along MCT (Figure 2). These thrust faults converged into the Main Himalaya Thrust (MHT), which forms the boundary with the subducted Indian Continental Plate, to cause tectonic emplacement of the Greater Himalaya $(\mathrm{GH})$, Lower Lesser Himalaya (LLH) and Upper Lesser Himalaya (ULT) along with partial melting and magmatic emplacement in the deep crust of the Himalaya fold-thrust belt [15]. The MCT was initiated in Early Eocene, 45-42 Ma [40, 41], and developed southward during the Oligocene and Early Miocene, followed by the Main Boundary Thrust (MBT) after Late Miocene, $10 \mathrm{Ma}$, south of the Himalaya Mountains, according to chronological data in Nepal [16]. An Oligocene-Early Miocene foreland basin formed south of the MCT (Figure 2). However, late Cenozoic thrusting (e.g., MBT) and uplift of the Himalaya Mountains lead to destruction of the Oligocene basin and erosion of its deposits and then formed the Siwalik foreland basin along the MBT after Late Miocene $[5,6,31]$.

3.2. Gangdese and Renbu-Zedong Thrust Systems. The Gangdese Thrust System (GTS) and Renbu-Zedong Thrust (RZT) both formed along the Yarlung Zangbo Suture, which forms the boundary between the Himalaya and Lhasa Blocks (Figure 2). The GTS in the southern Lhasa Block is characterized by southward thrusting along north-dipping faults of the Gangdese batholith and Linzizong volcanic rocks over the Late Cretaceous marine forearc sequence of the Xigaze Group and the Eocene-Oligocene Dazhuka Group [13]. The RZT in the northern Himalaya Block is characterized by northward thrusting of Mesozoic marine strata over the Gangdese batholith and Xigaze and Dazhuka Groups along south-dipping faults (Figure 3(a)). Major GTS faults were truncated and overthrusted by RZT along the suture in south of Lhasa to west of Xigaze (Figure 2). Analysis of ${ }^{39} \mathrm{Ar}^{-}{ }^{40} \mathrm{Ar}$ chronology suggests that GTS formed in 27-18.3 Ma with minimal displacement and slip rate of $\sim 46 \pm 9 \mathrm{~km}$ and $12 \pm 6 \mathrm{~mm} / \mathrm{a}$, respectively, [13] and that RZT formed in 19-11 Ma with minimal displacement and slip rate of $12 \mathrm{~km}$ and $\sim 2 \mathrm{~mm} / \mathrm{a}$, respectively [14].

3.3. Central Gangdese and North Gangdese Thrusts. The Central Gangdese Thrust (CGT) in central Lhasa Block (Figure 2) displaced tectonic slices of Carboniferous-Permian metamorphic rocks and Triassic-Jurassic limestone southward over Cretaceous volcanic-sedimentary strata (Figure 3(a)). Late Triassic limestone is thrust southward over Late Cretaceous lacustrine deposits of the Shexing Formation along the CGT north of Lhasa (Figure 4(g)), and Jurassic limestone of the Duodigou Formation is thrust southward over Cretaceous volcanic-sedimentary strata to form nappes along outer faults of the CGT south of Mozhugongka (Figure 3(a)). The CGT thrust faults north of Lhasa also are named the South Damxung Thrust (SDT) [32]. Carboniferous-Lower Permian slates are thrust over late Cretaceous-early Cenozoic red-beds of the Jingzhushan Formation along back faults of SDT east of Damxung [42]. Volcanic rocks of the Linzizong Group are offset by CGT thrust faults east of Mozhugongka. The minimal southward displacement of CGT is estimated to be $50 \mathrm{~km}$ according to the displacement of Jurassic limestone of the Dodigou Formation south of Mozhugongka (Figure 3(a)). Emplacement of Miocene porphyry granite produced local skarn in the Jurassic limestone nappes along the outer faults of CGT and formed metallic deposits at $\sim 15 \mathrm{Ma}$ [43]. These 
data indicate that CGT mainly formed in the Oligocene-Early Miocene.

The North Gangdese Thrust (NGT), which formed in the northern Lhasa Block, merges with CGT southeast of Jiali and west of Coqen (Figure 2). The NGT displaces varied units relatively southward. East of Xainza Proterozoic metamorphic rocks and Ordovician-Devonian limestone move over Carboniferous-Permian strata and Jurassic ophiolite. Paleozoic strata are thrust southward over Early Cretaceous marine strata and Late Cretaceous-Early Cenozoic red-beds west of Namco along a large thrust system, which has been termed the West Namco Thrust (WNT) [32]. Jurassic and upper Permian limestone are thrust southward over Late Cretaceous-Early Cenozoic red-beds and CarboniferousEarly Permian slate along its outer faults west of Jiali and north of Damxung (Figures 2 and 3).

3.4. Qiangtang Thrust Systems. Intense compression affecting the Qiangtang Block created several thrust systems that raised a central uplift, and this uplift divides the block into southern and northern parts (Figures 2 and 3(b)). The Saibu CoZagya Thrust (SZT), which forms the southern base of the block, has an associated reverse Nima-Silin Thrust (NST) in the adjacent northern Lhasa Block. To the north the higher Doma-Qixiang Co (DQT) and Xiaocaka-Shuanghu Thrusts (XST) cut the southern part of the Qiangtang Block, and the central uplift is raised above the latter. The northern Qiangtang Block is broken by the Longwei Co (LCT) and Northern Central (NCT) Thrusts. The Dogai Coren Thrust (DCT) lies at the upper contact of the Qiangtang Block with the Hohxil Block to the north.

Permian limestone and dolomite, Triassic sandstone and shale, and Jurassic limestone are thrust relatively southward over Paleocene-Eocene continental red-beds along faults of DCT, NCT, XST, and DQT (Figure 4(d)). Permian marble and slate, Jurassic limestone and ophiolite, and Cretaceous andesite are transported southward over Paleogene red-beds along the SZT (Figure 3(b)). However, northward directed thrust or reverse movement occurs along the south dipping North Tangula Thrust (NTT) [12], LCT, and NST (Figure 2). Jurassic limestone and sandstone are thrust northward over Paleocene-Eocene red-beds along LCT, and Early Cretaceous limestone, mudstone, and sandstone are thrust northward over Late Cretaceous conglomerate and Paleocene-Eocene red-beds along NST in the adjacent northern Lhasa Block (Figure 3(b)). These south-dipping thrusts are considered to be adjustments within the relatively southward moving, north-dipping Qiangtang Block and not separate movements. The early Cenozoic thrusts also formed a variety of tectonic slices, outliers, and nappes of Permian-Jurassic rocks and structural windows of Paleogene red-beds within the Qiangtang Block (Figure 2).

The Northern Central (NCT), Xiaocaka-Shuanghu (XST), Doma-Qixiang Co (DQT), and Saibu Co-Zagya Thrusts (SZT) formed a mega thrust system during the Early Cenozoic. This large system merges with the Bangoin-Nujiang Thrust (BNT) at Bangoin-Nujiang Suture (BNS), which marks the boundary between the Lhasa and
Qiangtang Blocks. Jurassic limestone is thrust southward over Paleocene-Eocene red-beds along BNT south of Ando; ophiolite slices are thrust southward along BNS over the northern Lhasa block (Figure 4(e)), and Cretaceous porphyry granite is thrust southeastward over Eocene-Oligocene redbeds, accompanied by tight folding along BNT west of Gar (Figure 4(f)). Southward displacement of this great Early Cenozoic thrust system is estimated to be $\sim 150 \mathrm{~km}$ as measured by the displacement of tectonic slices of TriassicJurassic marine strata overriding late Cretaceous-Eocene red-beds in the southern Qiangtang terrain (Figure 3(b)). The average southward slip rate ranges from $5.6 \mathrm{~mm} / \mathrm{a}$ to $7.4 \mathrm{~mm} / \mathrm{a}$ in Late Eocene-Oligocene based on ages of volcanic rock overlying the thrust faults [19]. Northward displacement of the reverse LCT is $16 \mathrm{~km}$ according to the offset of Jurassic limestone thrust over Paleocene-Eocene red-beds (Figure 3(b)).

3.5. Hohxil Thrust System. The Hohxil Thrust System (HXT) consists of north-dipping thrust faults with some minor reverse faults that cut the Hohxil Block above the Dogai Coren Thrust (DCT), which marks the border with the Qiangtang block (Figures 2 and 3). Jurassic limestone is moved southward over late Cretaceous-Early Cenozoic redbeds of the Fenghuoshan Group along the DCT with a minimal southward displacement of $25 \mathrm{~km}$ north of Dogai Coren Lake. Triassic shale and sandstone are thrust southward over red-beds of Fenghuoshan Group along HXT in Hohxil Block, and Late Cretaceous-Eocene red-beds of Fenghuoshan Group are thrusted southward over Oligocene brownish conglomerate and sandstone along gently-dipping faults of HXT north of Tuotuohe (Figures 3(d) and 4(c)). Oligocene basins and granites formed along the major thrust faults (Figure 2), which are covered unconformably by Early Miocene lacustrine deposits of Wudaoliang Group [10], demonstrating that the major thrusting occurred in the Oligocene.

3.6. South Kunlun Thrust. Southward thrusting occurred during Late Oligocene-Early Miocene in the southern East Kunlun Mountains to form the South Kunlun Thrust (SKT). Permian strata and Triassic rocks are thrust southward over the Paleocene-Eocene red-beds of Fenghuoshan Group (Figure 4(a)) and Oligocene brownish red conglomerate and sandstone of the Yaxicuo Group (Figure 4(b)). This movement along the SKT formed tectonic slices, low-angle thrust faults, multiscaled outliers, and nappe structures on both sides of the Dongdatan valley. Farther north to the Middle Kunlun Fault (MKF) a series of more steeply dipping thrusts repeat lower Paleozoic strata [33] (Figure 3(c)). Many of these steep thrusts are reactivated Silurian faults [34].

The SKT mainly developed during the Oligocene-Early Miocene and major thrust faults of SKT are covered unconformably by Miocene lacustrine deposits. Possible earlier movement is suggested by fault slivers of schist with ${ }^{39} \mathrm{Ar}$ -

${ }^{40} \mathrm{Ar}$ isotopic age of $26.5 \mathrm{Ma}$ and one of foliated granite with a fission track age of apatite of $26.0 \mathrm{Ma}$ that lie in thrusts of the SKT along the Dongdatan Valley [11]. The MKF 


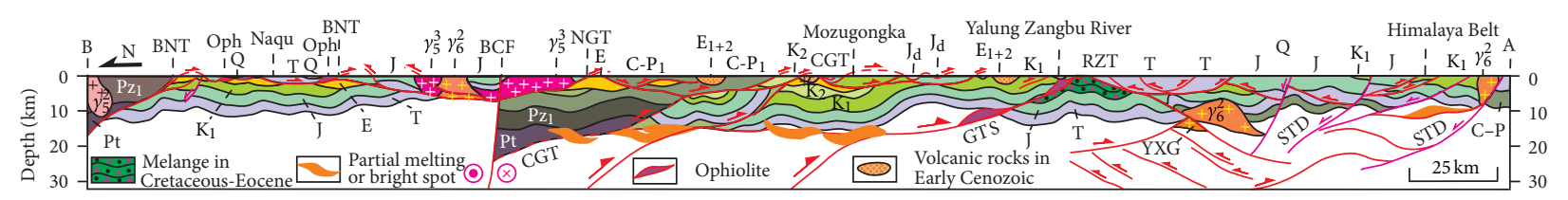

(a)

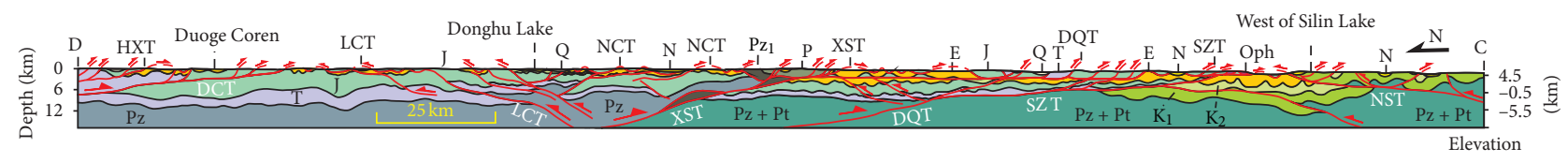

(b)

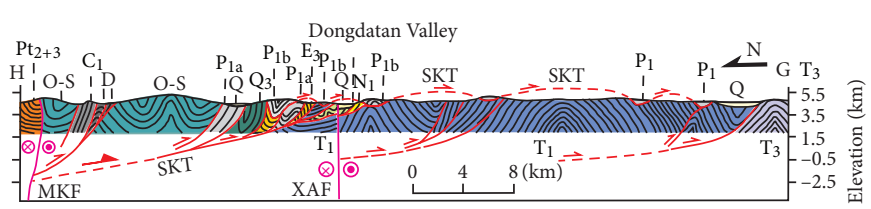

(c)

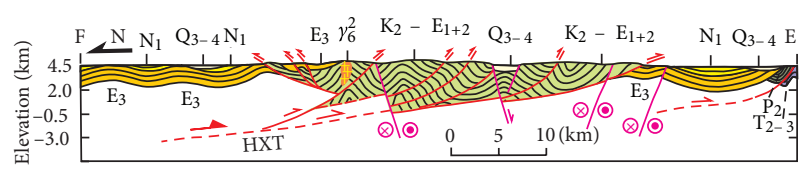

(d)

FIgURE 3: Cross sections across typical thrust systems in the Tibetan Plateau. Explanations: $\mathrm{Q}_{3-4}$ : Late Pleistocene-Holocene deposits; Q: Quaternary deposits; N: Miocene-Pliocene lacustrine strata; $\mathrm{N}_{1}$ : Early Miocene lacustrine deposits; E: Paleogene; $\mathrm{E}_{3}$ : Oligocene; $\mathrm{E}_{1+2}$ : Paleocene early Eocene; $\mathrm{K}_{2}$ : upper Cretaceous; $\mathrm{K}_{1}$ : lower Cretaceous; $\mathrm{P}_{1}$ : lower Permian; $\mathrm{P}_{1 a}$ : early Permian slate and schist; $\mathrm{P}_{1 b}$ : early Permian dolomite and marble; J: Jurassic marine strata; $\mathrm{J}_{d}$ : Jurassic limestone of Dodigou Formation; $\mathrm{T}$ : Triassic shale and sandstone; $\mathrm{T}_{3}$, upper Triassic slate and conglomerate; $\mathrm{T}_{2-3}$, middle-lower Triassic slate; $\mathrm{T}_{1}$ : lower Triassic slate and limestone; $\mathrm{C}_{1}$ : Carboniferous slate; $\mathrm{D}$ : Devonian metamorphic conglomerate and sandstone; O-S: Ordovician-Silurian schist and marble; $\mathrm{O}_{3}$ : Upper Ordovician limestone; $\mathrm{Pz}_{1}$ : Early Paleozoic schist and gneiss; $\mathrm{Pt}_{2+3}$ : middle-upper Proterozoic dolomite, marble and slate; Pt: Proterozoic gneiss; Oph: ophiolite; YXG: Yalaxianbo granite, deep extension of Yadoi leucogranite (YLG). BCF: Beng Co dextral-slip fault; MKF: Middle Kunlun fault; XAF: Xidatan active fault; other symbols are the same as in Figure 2. Locations of cross section A-B, C-D, E-F, and G-H are marked in Figure 2.

continued to move with sinistral-slip thrusting during the Late Miocene-Pliocene [11]. The southward displacement of Lower Permian dolomite over early Cenozoic red-beds along SKT is estimated to be $30-35 \mathrm{~km}$ with a minimal slip rate of $2.3 \sim 2.6 \mathrm{~mm} / \mathrm{a}$ [11]. Some minor reverse faults may occur within the northern Kunlun Mountains, southwest of the Qaidam Basin (Figure 2).

\section{Deep Structures in Middle-Lower Crust}

The thrust systems mapped at the surface have been extended downward with some confidence with the aid of seismic surveys. Several deep seismic profiles have revealed structures in the middle-lower crustal depths of the Tibetan Plateau, and these deep structures are compatible with the faults observed on the surface. The International Deep Profiling of Tibet and the Himalaya Mountains known as INDEPTH has been conducted in four stages that now extend from the Himalaya Mountains to the Qaidam Basin. INDEPTH-I made seismic reflections of the Main Himalaya Thrust and Moho beneath Himalaya Mountains [17], INDEPTH-II discovered brightspots and partial melting of the middle crust in southern Tibet $[18,44]$, and INDEPTH-III and INDEPTH-IV provided broad-band seismic data and receive function profiles of deep structures in northern Tibetan Plateau [22, 45]. Additional seismic reflections across Qiangtang Block have shown deep structures of the central Tibetan Plateau [20,21].

The Main Himalaya Thrust (MHT) at the upper boundary of the subducted Indian Continental Plate is seen only in southern and central Himalaya and disappears in the northern Himalaya belt [17], although north-dipping faults do occur in the middle-lower crust of northern Himalaya and southern Lhasa Blocks in the INDEPTH-I and II data [17, 18, 44] (Figure 5). These deep, generally parallel faults that show the northward subduction of the Indian continental plate caused dextral shearing of the crust into tectonic slices whose relatively movement southward has stacked them to cause crustal thickening in the Himalaya terrain and southern Lhasa Block.

A similar deep shearing of the middle-lower crust also is found in the central and northern Tibetan Plateau (Figure 5). Most faults dip northward $\sim 30^{\circ}$, although some faults curve and dip southward along more gently-dipping thrusts in central Tibet. The structural pattern of deep faults and associated folds indicate a thrusting and southward movement of the crust beneath the Qiangtang Block to cause thickening of middle-lower crust in central plateau. Curved faults exist locally in the lower crust, and some occur in the lithospheric mantle beneath Silin Co, where the Moho increases in depth to the south. Such structures near the Moho fit well with the hypothesis that Indian Continental Plate subducted northward to the Bangoin-Nujiang Suture (BNS). However, the Indian crust was sheared away from subducted continental plate, thrust southward along north-dipping faults and became accreted to the Himalaya terrain in the middlelower crust. Deep extensions of gently northward-dipping thrust faults also are present in the middle-lower crust in the northern Tibetan Plateau; some bound the Kunlun, Hohxil, 


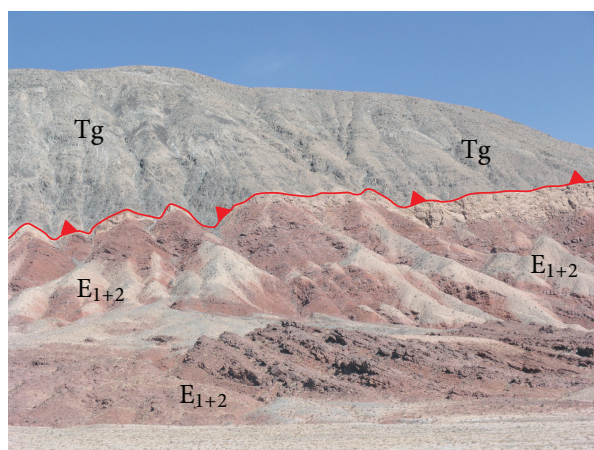

(a)

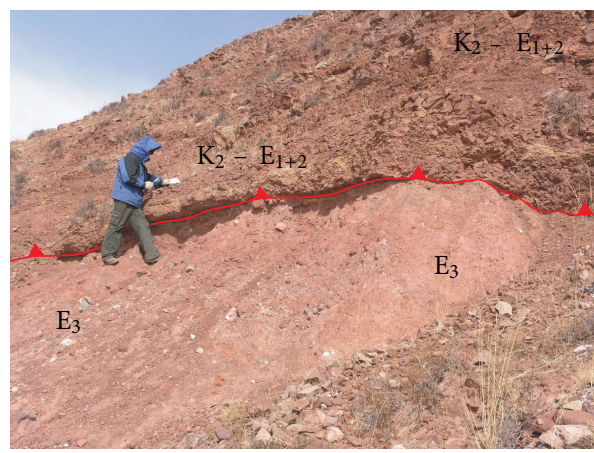

(c)

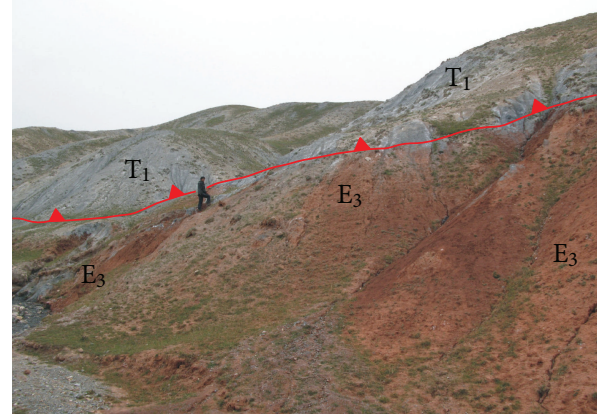

(b)

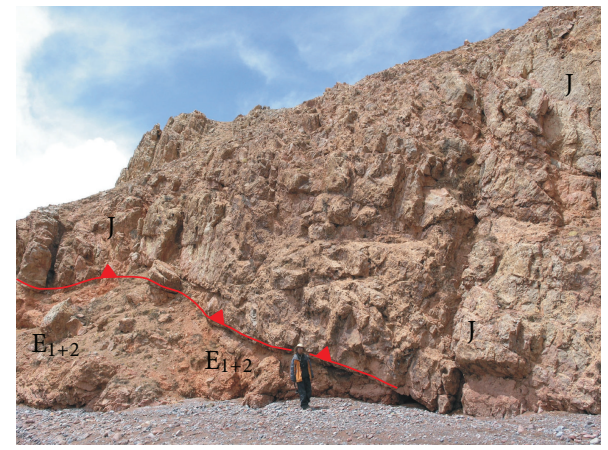

(d)

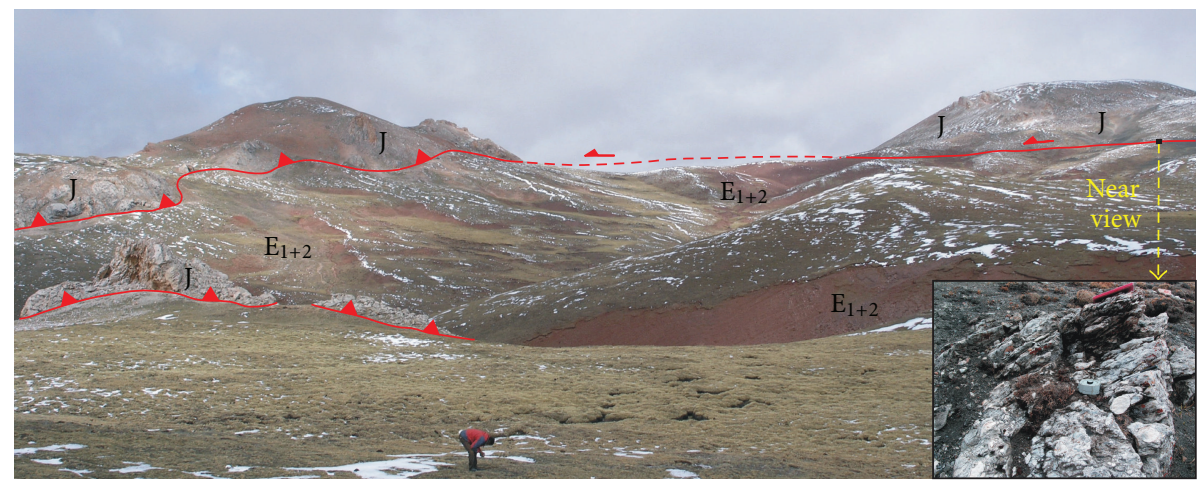

(e)

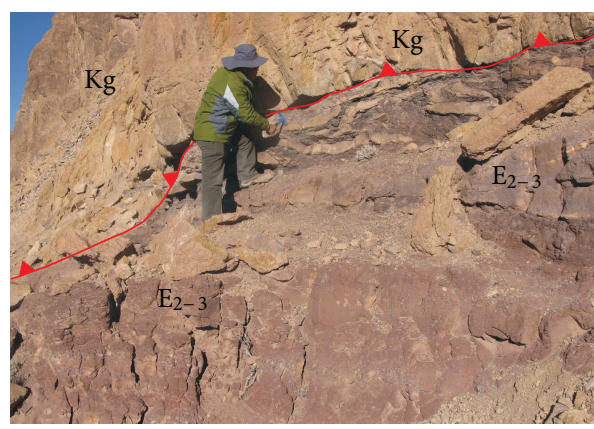

(f)

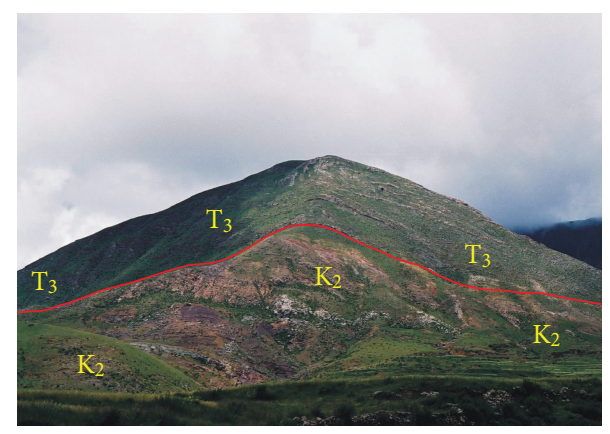

(g)

FIgURE 4: Photos of Late Eocene-Oligocene southward thrust in the Tibetan Plateau. Explanation: (a): view northward at Triassic granodiorite (Tg) thrust over Paleocene-Eocene red-beds $\left(\mathrm{E}_{1+2}\right)$ along SKT in southern Kunlun Mountains; (b): view northward at Early Triassic slate $\left(\mathrm{T}_{1}\right)$ thrust over Oligocene red-beds $\left(\mathrm{E}_{3}\right)$ along SKT in southern Kunlun Mts.; $(\mathrm{c})$ : view northward at Upper Cretaceous-Eocene red-beds $\left(\mathrm{K}_{2}-\mathrm{E}_{1+2}\right)$ thrust over Oligocene lacustrine deposits $\left(\mathrm{E}_{3}\right)$ along HXT in north of Tuotuohe; $(\mathrm{d})$ ): view northwestward at Jurassic limestone $(\mathrm{J})$ thrust over Paleocene-Eocene red-beds $\left(\mathrm{E}_{1+2}\right)$ along NCT north of Shuanghu; (e): view northwestward at Jurassic limestone (J) thrust over PaleoceneEocene red-beds $\left(\mathrm{E}_{1+2}\right)$ and breccia formed by thrusting along BNT in south of Ando; (f): view northwestward at Cretaceous porphyry granite $(\mathrm{Kg})$ thrust over Eocene-Oligocene red-beds $\left(\mathrm{E}_{2-3}\right)$ along BNT in east of Gar; $(\mathrm{g})$ : view northward at upper Triassic limestone $\left(\mathrm{T}_{3}\right)$ thrust over upper Cretaceous-Paleocene lacustrine strata $\left(\mathrm{K}_{2}\right)$ along CGT in northeast of Lhasa. Locations for photos are marked in Figure 2. 


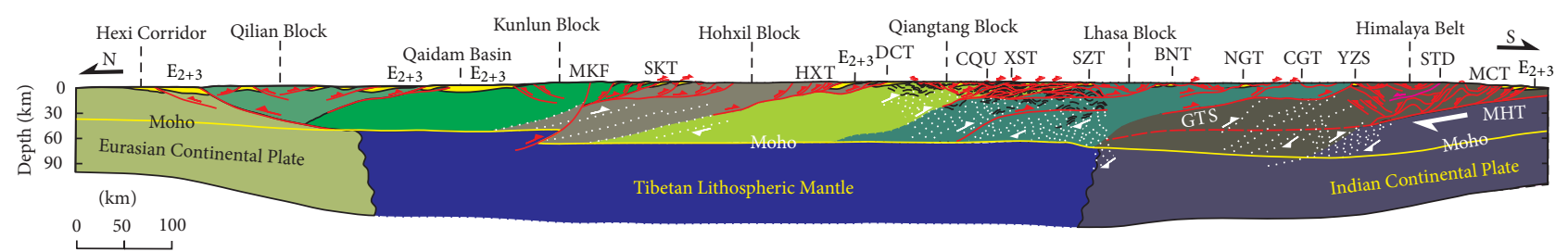

FIGURE 5: Generalized crustal profile across the Tibetan Plateau. Explanation: red line: major thrust system; dashed red line: upper boundary of Indian continental crust shearing thrusted away from subducted Indian Continental Plate; dotted white lines: deep shearing thrust in middle-lower crust; black fine lines: strata or foliation in middle-upper crust. Deep structures of Himalaya and southern Tibet are inferred from seismic reflection profiles of INDEPTH-I II [17, 18]; deep structures of central Tibetan Plateau are inferred [19] from seismic reflection profiles across Qiangtang Block [20,21], and the receiver function profile and wide angle seismic data of INDEPTH-IV [22, 23] in the northern Tibetan Plateau were used to interpret middle-lower crustal structures shown herein [24]. Deep structures marked by the black and white dotted lines are new interpretations of the seismic profiles. Letter symbols are the same as on Figures 2 and 3.

and Qiangtang Blocks, and the Middle Kunlun fault offsets the Moho.

\section{Age of Cenozoic Thrusts}

Thrusts in the upper crust such as GTS in south Tibet and BNT in central Tibet (Figure 5) formed in the brittle-ductile transition zone at depths of $\sim 15-20 \mathrm{~km}$, and seismic bright spots suggesting partial melting occurs along GTS in the southern Lhasa Block (Figure 3(a)). Partial melting along GTS may have resulted in the emplacement of Early Miocene granites in central Lhasa block [46]. The isotopic ages of the granites and metallogeny of porphyry granites provide time constraints for movement along the GTS detachment. The foliated syntectonic Nyainqentanglha granite formed in 18.3-11.1 Ma [47], and copper-bearing porphyry granites in southern Gangdese Mountains formed in 14.5-17.7 Ma [43], indicating that thrusting was underway along the GTS in Early Miocene (18-11 Ma) beneath the central Lhasa Block. This is $\sim 10 \mathrm{Ma}$ later than the indicated age of the southern outer thrusts of GTS [13]. GTS apparently began earlier in south and developed northward.

The geochemistry of the Eocene-Oligocene igneous rocks [48] in the Qiangtang and Hohxil Blocks of the central and northern plateau is similar to Miocene adakitic porphyry granites in the Gangdese tectonic belt [49]. Because the Miocene porphyry granites in the Gangdese tectonic belt are geodynamically related to partial melting along GTS detachment [46], these Eocene-Oligocene rocks also are inferred to be the result of this melting thus, their isotopic ages provide time constraints for the deep thrusts. The U- $\mathrm{Pb},{ }^{39} \mathrm{Ar}-{ }^{40} \mathrm{Ar}$, and $\mathrm{K}$-Ar isotopic ages of trachyte, dacite, granite, and syenite formed in Eocene-Oligocene in Qiangtang and Hohxil Blocks range from 44.3-44.0 Ma in northern Qiangtang Block to 38.3-26.5 Ma in southern Qiangtang Block (Table 1). This suggests that the deep thrusts of the Qiangtang Block may have been initiated soon after the India-Eurasia continental collision in early Cenozoic and developed southward with associated partial melting.

Major faults moved over Late Cretaceous-Eocene redbeds and Oligocene brownish red-beds in the northern Lhasa, Qiangtang, Hohxil, and Kunlun Blocks, and most thrust faults were covered unconformably by only weakly deformed Miocene lacustrine deposits in the central and northern Tibetan Plateau [10]. This demonstrates that the intense thrusting occurred in Late Eocene-Early Miocene in the Tibetan Plateau. However, the Himalaya Thrust developed progressively southward from the Oligocene-Early Miocene MCT through Late Miocene MBT to Quaternary MFT along MHT. Far to the north the intensive thrusting in the Qilian Mountains was mainly initiated since Miocene $[5,39]$.

\section{Conclusions and Discussion}

A comprehensive depiction of the major thrust systems forming the early Cenozoic structural framework across the Himalayan Mountains, and the Tibetan Plateau now is revealed by the regional mapping and deep seismic surveys. The seismic data show many thrusts to mid-lower crustal depth. Some thrust systems bound the Himalaya, Lhasa, Qiangtang, Hohxil, and Kunlun Blocks, and a few mark suture zones.

Early Cenozoic compression due to the northward subduction of the Indian continental plate squeezed and telescoped the Tibetan region to create a series of north-dipping thrust systems in the upper and middle-lower crust of the present narrower Himalayan Mountains and Tibetan Plateau. Continued movement stacked up the overlapping thrust sheets to form the thickened crust of the region. The majority of the thrust faults in the upper crust dip northward, leading to relative southward displacement, although some reverse, south-dipping thrusts exist in the Himalaya (RZT), northern Lhasa (NST), northern Qiangtang (NTS), and northern Kunlun Blocks, but southward movement is dominate in the middle-lower crust of the Tibetan Plateau. The south-dipping thrusts appear to be due to local adjustments within thrust sheets when the back of a sheet moves faster than the toe. The displacement by thrusting first caused shortening and thickening of middle-lower crust and then to shortening and southward thrusting in the upper crust to form the multiple thrust systems.

The thrusting took place between the Eocene and Early Miocene. The MCT chiefly formed in Late Eocene-Early 
TABLE 1: Isotopic ages of early Cenozoic volcanic rocks and Miocene thermal events in the Tibetan Plateau.

\begin{tabular}{|c|c|c|c|}
\hline Magmatic rock and sampling location & Dating method/material & Isotopic ages & References \\
\hline Dongyuehu andesite (DHT) & SHRIMP U-Pb/zircon & $44.3 \pm 1.8 \mathrm{Ma}$ & Dong et al., 2008 [50] \\
\hline Gongjue dacite (GJD) & $\mathrm{K}$-Ar linear isochron & $44.2 \pm 0.9 \mathrm{Ma}$ & Li et al., 2004 [51] \\
\hline Yuejinla trachyandesite (YLT) & $\mathrm{K}$-Ar/whole rock & $43.0-32.6 \mathrm{Ma}$ & Zhu et al., 2005 [52] \\
\hline Purogangri granite (PGG) & K-Ar/biobite & $41.1 \pm 0.5 \mathrm{Ma}$ & Zhu et al., 2005 [52] \\
\hline Zurkanwula dacite (ZWD) & ${ }^{39} \mathrm{Ar}-{ }^{40} \mathrm{Ar} /$ whole rock & $41.1 \pm 0.8 \mathrm{Ma}$ & Lin et al., 2003 [53] \\
\hline Dogecuoren andesite (DCA) & $\mathrm{K}$-Ar/whole rock & $41.6-32.6 \mathrm{Ma}$ & Zhu et al., 2005 [52] \\
\hline Saiduopu granite (SGG) & $\mathrm{U}-\mathrm{Pb} /$ zircon & $40.6 \pm 3.1 \mathrm{Ma}$ & Duan et al., 2005 [54] \\
\hline Tangula granite at Geladandong (SGG) & $\mathrm{U}-\mathrm{Pb} /$ zircon & $40.0 \pm 3.0 \mathrm{Ma}$ & Li et al., 2006 [12] \\
\hline Bilog Co trachite (BCT) & K-Ar/whole rock & $38.3 \pm 3.3 \mathrm{Ma}$ & Lai et al., 2006 [48] \\
\hline Nuangqian volcanic rocks (NQV) & K-Ar/whole rock & $38.0-34.0 \mathrm{Ma}$ & Lai et al., 2006 [48] \\
\hline Yulong Porphyry Copper Deposit (YCP) & Re-Os/Molybdenite & $35.6 \pm 0.2 \mathrm{Ma}$ & Li et al., $2004[1,51]$ \\
\hline Yaoan porphyry syenite (YPS) & K-Ar/whole rock & $34.0-47.0 \mathrm{Ma}$ & Hou et al., 2004 [55] \\
\hline Beiya porphyry syenite (BPS) & $\mathrm{K}$-Ar/whole rock & $45.0 \pm 2.0 \mathrm{Ma}$ & Hou et al., 2004 [55] \\
\hline Machangqing Copper porphyrite (MCP) & Rb-Sr linear isochron & $36.0 \pm 1.2 \mathrm{Ma}$ & Hou et al., 2004 [55] \\
\hline Ejimaima andesite (EMA) & $\mathrm{K}$-Ar/whole rock & $34.8 \pm 1.2 \mathrm{Ma}$ & Zeng et al., 2002 [56] \\
\hline North Deqen volcanic rocks (NDV) & K-Ar/whole rock & $33.0 \pm 1.5 \mathrm{Ma}$ & Li et al., $2004[1,51]$ \\
\hline Andar Co trachite (ACT) & $\mathrm{K}$-Ar/whole rock & $32.6 \pm 0.6 \mathrm{Ma}$ & Wang et al., 2005 [57] \\
\hline Zougoyouchaco trachyandesite (ZCT) & ${ }^{39} \mathrm{Ar}-{ }^{40} \mathrm{Ar} /$ whole rock & $30.5 \pm 0.6 \mathrm{Ma}$ & Li et al., 2006 [58] \\
\hline Yulinshan leucite phonolite (YSP) & ${ }^{39} \mathrm{Ar}-{ }^{40} \mathrm{Ar} /$ leucite & $27.8 \pm 0.8 \mathrm{Ma}$ & Cai et al., 2002 [59] \\
\hline Fenghuoshan granite (FSG) & SHRIMP U-Pb/zircon & $27.6 \pm 0.5 \mathrm{Ma}$ & Wu et al., 2008 [10] \\
\hline Huochetou Shan basanite (HCB) & ${ }^{39} \mathrm{Ar}^{40} \mathrm{Ar} /$ biobite & $26.7 \pm 0.7 \mathrm{Ma}$ & Liu et al., 2004b [60] \\
\hline Manshan porphyry syenite (MPS) & SHRIMP U-Pb/zircon & $26.5 \pm 0.8 \mathrm{Ma}$ & Wei et al., 2007 [61] \\
\hline Yadoi leucogranite (YLG) & SHRIMP U-Pb/zircon & $35.3 \pm 1.1 \mathrm{Ma}$ & Gao et al., 2009 [62] \\
\hline Kude granite (KG) & $\mathrm{U}-\mathrm{Pb} /$ zircon & $27.5 \pm 0.5 \mathrm{Ma}$ & Zhang et al., 2004 [63] \\
\hline
\end{tabular}

Explanation: sampling locations of Magmatic rocks are Marked in Figure 2.

Miocene; GTS formed in Late Oligocene-Early Miocene, 27-18.3 Ma, in southern Gangdese and extended into the deep crust in 18.3-11.1 Ma in the central Lhasa block; SKT formed in Oligocene-Early Miocene; HXT formed in Late Eocene-Oligocene. Intensive thrusting was initiated in the northern Qiangtang block soon after the India-Eurasia continental collision in early Cenozoic and then developed southward to form the Southern Qiangtang Thrust in Late EoceneEarly Oligocene. Displacement and rate of movement during the early Cenozoic are difficult to determine due to erosion of the upper thrust plates and the few available precise dates. Normally only minimal offsets and rates can be determined, such as the more accurate ones for the SKT, HXT, QTS, CGT, and GTS. The minimal southward displacements of SKT, HXT, South Qiangtang Thrust, and CGT are estimated at $30 \mathrm{~km}, 25 \mathrm{~km}, 150 \mathrm{~km}$, and $50 \mathrm{~km}$, respectively, with average slip rates of SKT, South Qiangtang Thrust, and GTS being $2.3 \sim 2.6 \mathrm{~mm} / \mathrm{a}, 5.6-7.4 \mathrm{~mm} / \mathrm{a}$, and $12 \pm 6 \mathrm{~mm} / \mathrm{a}$, respectively, during the Oligocene-Early Miocene.

This timing, which is derived from the field data, is in general agreement with inferences from paleomagnetic studies. Such studies provide estimates of the subduction velocity of the Indian continental plate that relates to the thrusting and crustal thickening process in the Himalayan-Tibetan region. The suggested northward plate velocity changed from $90 \mathrm{~mm} / \mathrm{a}$ in the Paleocene-Early Eocene to $\sim 55 \mathrm{~mm} / \mathrm{a}$ in Late Eocene-Oligocene and has remained $\sim 50 \mathrm{~mm} / \mathrm{a}$ since Early
Miocene with the rapid decrease of northward velocity of the Indian plate occurring 45-43 Ma [64]. This corresponds to a change from the Tethys oceanic plate subduction to India-Eurasia continental collision, which is marked by the initial northward subduction of Indian Continental Plate in $\sim 54-40 \mathrm{Ma}$ in eastern Himalaya [65], 50-42 Ma in central Himalaya $[6,40,41,66,67]$, and $\sim 57$ Ma in western Himalaya [68]. This timing is consistent with earlier paleomagnetic data which suggested that the India-Eurasia continent collision began $\sim 50 \mathrm{Ma}[69,70]$. It is further inferred that the northward subduction of the Indian continental plate is $1,183 \mathrm{~km}$ with northward slip rate $\sim 55 \mathrm{~mm} / \mathrm{a}$ during Middle Eocene-Oligocene, $\sim 45-23.5 \mathrm{Ma}$ [64]. This would increase the thickness of the Tibetan crust to $\sim 60 \mathrm{~km}$, which is about the present Moho depth in northern Tibet, before 23.5 Ma, if all the crust sheared away from the subducted Indian continental plate were accreted to the crust of the Himalaya terrain and Tibetan Blocks along deep thrusts (Figure 5). Or the crust might double in thickness in the Tibetan Plateau several million years after $23.5 \mathrm{Ma}$ if part of the Indian Continental Crust were subducted to the mantle.

Geologic field evidence demonstrates that the thickened Tibet crust was buoyed upwards in Early-Middle Miocene. Southern Tibet was uplifted to between $4,638 \pm 847 \mathrm{~m}-$ $4,689 \pm 895 \mathrm{~m}$ before $\sim 15 \mathrm{Ma}$ [71] and the Lunpola Basin rose to its present elevation before Early Miocene [72]. Large lakes formed in Early Miocene [10], and their lacustrine deposits, 
which only show weak deformation, are unconformably over major thrust systems in northern Lhasa, Qiangtang, Hohxil, and Kunlun Blocks. The intense thrusting is indicated to have stopped before Early Miocene in the central and northern Tibetan Plateau. This agrees with the crustal extension beginning in Middle and Late Miocene in the Qiangtang and Lhasa Blocks, respectively $[73,74]$. However, intensive thrusting and tectonic contraction appear to have continued active in the southern Himalaya [5], Namche Barwa Syntaxis [65], West Kunlun [38], Qilian [39], Longmenshan Mountains [7] and the Jiuquan [75], Guide [76, 77], and Linxa Basins [78] in late Cenozoic.

\section{Acknowledgments}

This research was supported by Ministry of Land and Resources of China under Grant Sinoprobe-02, China Geological Survey under Grant nos. 1212011221111 and 1212011120185, and Ministry of Science and Technology of China under Grant 2006DFB21330. The authors thank Professor Keiko Hattori and Dr. Josep Pares for giving their detail suggestions to improve the paper. They are also grateful to Professor Gao Rui and Dr. Lu Zhanwu who provided their seismic reflection data for interpretation of deep structures in the central Tibetan Plateau.

\section{References}

[1] G. Li, X. Wan, W. Liu, D. Liang, and H. Yun, "Discovery of Palaeogene marine strata along Yaluzangbu suture and its tectonic significance," Science in China D, vol. 34, no. 3, pp. 228-240, 2004.

[2] X. Wan, J. Li, S. Zhang, and L. Wu, "The late cretaceouspaleocene planktonic foraminifera from Zanda, western Tibet and their chronolostratigraphic implications," ACTA Micropalaeontologica Sinica, vol. 22, no. 1, pp. 10-18, 2005.

[3] B. Sun, Z. Liu, and Z. Wang, "New knowledge on geology of Karshi depression in southwest Tarim," Xinjiang Geology, vol. 21, no. 1, pp. 78-84, 2003.

[4] K. J. Matthew and P. D. Christopher, "Petrologic case for Eocene slab breakoff during the Indo-Asian collision," Geology, vol. 30, no. 7, pp. 591-594, 2002.

[5] A. Yin and T. M. Harrison, "Geologic evolution of the Himalayan-Tibetan orogen," Annual Review of Earth and Planetary Sciences, vol. 28, pp. 211-280, 2000.

[6] J. F. Dewey, R. M. Shackleton, C. Chengfa, and Y. Sun, "The tectonic evolution of the Tibetan plateau," Philosophical Transactions of the Royal Society A, vol. 327, no. 1594, pp. 379-413, 1988.

[7] M. K. Clark and L. H. Royden, "Topographic ooze: building the eastern margin of Tibet by lower crustal flow," Geology, vol. 28, no. 8, pp. 703-706, 2000.

[8] P. Tapponnier, Z. Xu, F. Roger et al., "Oblique stepwise rise and growth of the tibet plateau," Science, vol. 294, no. 5547, pp. 1671-1677, 2001.

[9] C. Beaumont, R. A. Jamieson, M. H. Nguyen, and S. Medvedev, "Crustal channel flows: 1 . Numerical models with applications to the tectonics of the Himalayan-Tibetan orogen," Journal of Geophysical Research B, vol. 109, no. 6, Article ID B06406, 29 pages, 2004.
[10] Z. Wu, P. J. Barosh, Zh. Wu, D. Hu, X. Zhao, and P. Ye, "Vast early Miocene lakes of the central Tibetan plateau," Bulletin of the Geological Society of America, vol. 120, no. 9-10, pp. 1326-1337, 2008.

[11] Z. Wu, P. Ye, P. J. Barosh, D. Hu, W. Zhao, and Z. Wu, "Late oligocene-early miocene thrusting in southern East Kunlun Mountains, northern Tibetan plateau," Journal of Earth Science, vol. 20, no. 2, pp. 381-390, 2009.

[12] Y. Li, C. Wang, H. Yi, Z. Liu, and Y. Li, "Cenozoic thrust system and uplifting of the Tanggula Mountain, northern Tibet," Acta Geologica Sinica, vol. 80, no. 8, pp. 1118-1130, 2006.

[13] A. Yin, T. M. Harrison, F. J. Reyerson, W. Chen, W. S. F. Kidd, and P. Copeland, "Tertiary structural evolution of the Gangdese thrust system in southern Tibet," Journal of Geophysical Research, vol. 99, pp. 18175-18201, 1994.

[14] Q. Xavier, M. Grove, O. M. Lovera, M. Harrison, and A. Yin, "Thermal evolution and slip history of the Renbu Zedong Thrust, southeastern Tibet," Journal of Geophysical Research B, vol. 102, no. 2, pp. 2659-2679, 1997.

[15] P. G. Decelles, D. M. Robinson, J. Quade et al., "Stratigraphy, structure, and tectonic evolution of the Himalayan fold-thrust belt in Western Nepal," Tectonics, vol. 20, no. 4, pp. 487-509, 2001.

[16] D. M. Robinson, P. G. Decelles, C. N. Garzione, O. N. Pearson, T. M. Harrison, and E. J. Catlos, "Kinematic model for the Main Central Thrust in Nepal," Geology, vol. 31, no. 4, pp. 356-362, 2003.

[17] K. Zhang, G. Wang, J. Ji et al., "Paleogene-Neogene stratigraphic realm and sedimentary sequence of the Qinghai-Tibet Plateau and their response to uplift of the Plateau," Science China Earth Sciences, vol. 53, no. 9, pp. 1271-1294.

[18] L. D. Brown, W. Zhao, K. D. Nelson et al., "Bright spots, structure, and magmatism in southern Tibet from INDEPTH seismic reflection profiling," Science, vol. 274, no. 5293, pp. 1688-1690, 1996

[19] Z. Wu, P. Ye, D. Hu, and L. Lu, "Paleogene thrust system in Southern Qiangtang Basin, Central Tibetan Plateau," Geological Bulletin of China, vol. 30, no. 7, pp. 1009-1016, 2011.

[20] J. Wang, J. Ding, C. Wang, and F. Tan, Survey and Evaluation on Target Areas for Oil-Gas Exploration in the Tibetan Plateau, Geological Publishing House, Beijing, China, 2009.

[21] R. Gao, Z. Lu, X. Xiong et al., "SINOPROBE deep seismic reflection profiling across the Bangong-Nujiang suture, central Tibet," in Proceedings for the 25th Himalaya-Karakoram-Tibet Workshop, M. L. Leech, Ed., 2010.

[22] M. S. Karplus, W. Zhao, S. L. Klemperer et al., "Injection of Tibetan crust beneath the south Qaidam Basin: evidence from INDEPTH IV wide-angle seismic data," Journal of Geophysical Research B, vol. 116, no. 7, Article ID B07301, 2011.

[23] D. Shi, W. Zhao, M. Feng et al., "Primary results of receive function profile of INDEPTH-IV across northern Tibetan Plateau," in Proceedings of the Workshop on International Deep Profiling of Tibet and Himalaya, 2011.

[24] P. J. Barosh, Z. Wu, D. Hu, P. Ye, W. Zhao, and Zh. Wu, "Crustal structure of the northern Tibetan Plateau along the INDEPTH-IV seismic traverse," American Geophysical Union, Fall Meeting, Abstracts and Proceedings, 2012.

[25] W. S. F. Kidd, Y. Pan, C. Chang et al., "Geological mapping of the 1985 Chinese-British Tibetan (Xizang-Qinghai) Plateau geotraverse route," Philosophical Transactions of the Royal Society $A$, vol. 327, pp. 287-305, 1988. 
[26] Tibetan Bureau of Geology and Mineral Resources, Regional Geology of Tibetan Autonomous Region, Geological Publishing House, Beijing, China.

[27] Qinghai Bureau of Geology and Mineral Resources, Regional Geology of Qinghai Province, Geological Publishing House, Beijing, China, 1991.

[28] Yunan Bureau of Geology and Mineral Resources, Regional Geology of Yunan Province, Geological Publishing House, Beijing, China, 1990.

[29] Sichuan Bureau of Geology and Mineral Resources, Regional Geology of Sichuan Province, Geological Publishing House, Beijing, China, 1991.

[30] G. Pan, J. Ding, D. Yao, and L. Wang, Geological map of Qinghai-Xizang (Tibet) Plateau and adjacent areas, Chengdu Cartographic Publishing House, Chengdu, China, 1-140, 2004.

[31] G. Pan, L. Wang, R. Li et al., "Tectonic evolution of the Tibetan Plateau," Journal of Asian Earth Sciences, vol. 53, pp. 3-14, 2012.

[32] Z. Wu, D. Hu, P. Ye, X. Zhao, and Q. Liu, "Thrusting of the North Lhasa Block in the Tibetan Plateau," ACTA Geologica Sinica, vol. 78, no. 1, pp. 246-259, 2004.

[33] P. J. Barosh, D. Hu, Z. Wu, and Y. Zhang, "Map at scale 1:25, 000 and geology of the Shuinichang (Cement Factory) quadrangle, northern Kunlun Mountains," Published by Institute of Geomechanics, Chinese Academy of Geological Sciences, Beijing, China, 2009.

[34] P. J. Barosh, Z. Wu, D. Hu et al., "Deep, late? Silurian and late oligocene-early miocene thrusts crossing the INDEPTHIV survey traverse in the Middle Kunlun Mountains, Northern Tibetan Plateau," in Proceedings of the International Symposium on Deep Exploration into the Lithosphere, Sinoprobe, pp. 195-196, Chinese Academy of Geological Sciences, Beijing, China, 2011.

[35] K. Zhang, G. Wang, J. Ji et al., "Paleogene-Neogene stratigraphic realm and sedimentary sequence of the Qinghai-Tibet Plateau and their response to uplift of the plateau," Science China Earth Sciences, vol. 53, no. 9, pp. 1271-1294, 2010.

[36] C. Wang, X. Zhao, Z. Liu et al., "Constraints on the early uplift history of the Tibetan Plateau," Proceedings of the National Academy of Sciences of the United States of America, vol. 105, no. 13, pp. 4987-4992, 2008.

[37] Z. Liu, X. Zhao, C. Wang, S. Liu, and H. Yi, "Magnetostratigraphy of tertiary sediments from the Hoh Xil Basin: implications for the Cenozoic tectonic history of the Tibetan Plateau," Geophysical Journal International, vol. 154, no. 2, pp. 233-252, 2003.

[38] S. Liu, B. Qiu, H. Yin, J. L. Li, S. M. Zhai, and W. H. Li, "Structural characteristics of Wuboer thrust belts in the foreland of West Kunlun Mountain," Acta Petrolei Sinica, vol. 26, no. 6, pp. 16-19, 2005.

[39] A. Yin, Y. Dang, L. Wang et al., "Cenozoic tectonic evolution of Qaidam basin and its surrounding regions (Part 1): The southern Qilian Shan-Nan Shan thrust belt and northern Qaidam basin," Bulletin of the Geological Society of America, vol. 120, no. 7-8, pp. 813-846, 2008.

[40] K. V. Hodges, R. R. Parrish, and M. P. Searle, "Tectonic evolution of the central Annapurna Range, Nepalese Himalayas," Tectonics, vol. 15, no. 6, pp. 1264-1291, 1996.

[41] L. Zeng, L. Gao, K. Xie, and J. Zeng, "Mid-Eocene high Sr/Y granites in the Northern Himalayan Gneiss Domes: melting thickened lower continental crust," Earth and Planetary Science Letters, vol. 303, no. 3-4, pp. 251-266, 2011.
[42] P. Kapp, P. G. DeCelles, A. L. Leier et al., "The Gangdese retroarc thrust belt revealed," GSA Today, vol. 17, no. 7, pp. 4-9, 2007.

[43] Z. Rui, Z. Hou, G. Li, L. Zhang, L. Wang, and S. Tang, "Subduction, collision, deep fault, adakite and porphyry copper deposits," Geology and Exploration, vol. 42, no. 1, pp. 1-6, 2006.

[44] K. D. Nelson, W. Zhao, L. D. Brown et al., "Partially molten middle crust beneath southern Tibet: synthesis of project INDEPTH results," Science, vol. 274, no. 5293, pp. 1684-1688, 1996.

[45] W. Zhao, K. D. Nelson, J. Che et al., "Deep seismic reflection evidence for continental underthrusting beneath southern Tibet," Nature, vol. 366, no. 6455, pp. 557-559, 1993.

[46] Z. Wu, P. J. Barosh, X. Zhao, Zh. Wu, D. Hu, and Q. Liu, "Miocene tectonic evolution from dextral-slip thrusting to extension in the Nyainqentanglha region of the Tibetan Plateau," ACTA Geologica Sinica, vol. 81, no. 3, pp. 365-384, 2007.

[47] Q. Liu, Z. Wu, D. Hu et al., "SHRIMP U-Pb zircon dating on Nyainqentanglha granite in central Lhasa block," Chinese Science Bulletin, vol. 49, no. 1, pp. 76-82, 2004.

[48] S. Lai, J. Qing, Y. Li, and X. Zheng, "Cenozoic volcanic rocks in the Bêlog Co area, Qiangtang, northern Tibet, China: petrochemical evidence for partial melting of the mantle-crust transition zone," Geological Bulletin of China, vol. 25, no. 1-2, pp. 64-69, 2006.

[49] Z. Hou, X. Meng, X. Qu, and Y. Gao, “Copper ore potential of adatic intrusives in the Gangdise copper belt: constraints from rock phase and deep melting process," Mineral Deposits, vol. 24, no. 2, pp. 108-121, 2005.

[50] Y. Dong, Q. Wang, J. Xu, and F. Zi, “Dongyue Lake adakitic volcanic rocks with high $\mathrm{Mg}$ in north Qiangtang block: petrogenesis and its tectonic implication," Acta Petrologica Sinica, vol. 24, no. 2, pp. 291-302, 2008.

[51] Z. Li, Z. Chen, X. Li, C. Gizbert, and B. C. Burchfiel, "K-Ar ages of Cenozoic volcanic rocks from Gongjue Basin in eastern Tibet," Journal of China University of Geosciences, vol. 29, no. 3, pp. 278-282, 2004.

[52] W. Zhao, P. Kumar, J. Mechie et al., "Tibetan plate overriding the Asian plate in central and northern Tibet," Nature Geoscience, vol. 4, pp. 870-873, 2011.

[53] J. Lin, H. Yi, B. Zhao, B. H. Li, Z. Q. Shi, and J. J. Huang, "39 Ar${ }^{40} \mathrm{Ar}$ isotopic dating and its implication of Cenozoic volcanic rocks from Zurkenwula Mountain area, northern Tibetan," Mineral and Petrology, vol. 23, no. 3, pp. 31-34, 2003.

[54] Z. Duan, Y. Li, Y. Zhang, Y. Li, and M. Wang, "Zircon $\mathrm{U}-\mathrm{Pb}$ age, continent dynamics significance and geochemical characteristics of the Mesozoic and Cenozoic granites from the Tanggula range in the Qinghai-Tibet Plateau," Acta Geologica Sinica, vol. 79, no. 1, pp. 88-97, 2005.

[55] Z. Hou, D. Zhong, and W. Deng, "A tectonic model for porphyry copper-molybdenum-gold metallogenic belts on eastern margin of the Qianghai-Tibet Plateau," Geology in China, vol. 31, no. 1, pp. 1-14, 2004.

[56] Q. Zeng, G. Mao, G. Cheng et al., "Geological survey report and geological map at scale 1:250, 000 of Ripeigan Co Quadrangle," Published by Tibet Geological Survey, Lhasa, China, 2002.

[57] Q. Wang, W. Yang, Z. Zhang, Y. Yang, J. Wu, and A. Dong, "Geological characteristics of Neogene volcanic rocks in the Heishi North Lake area, northwestern Tibet and their implications for Neogene tectonic evolution," Geological Bulletin of China, vol. 24, no. 1, pp. 80-86, 2005. 
[58] C. Li, X. Huang, S. Mou, and X. Chi, "Age dating of the Zougouyouchacuo volcanic rocks and age determination of the Kangtog Formation in southern Qiangtang, northern Tibet, China," Geological Bulletin of China, vol. 25, no. 1-2, pp. 226-228, 2006.

[59] C. Li, Z. Zhu, and X. Chi, "Isotope chronology of volcanic rocks in the Yulinshan Formation in the Gaize area, northern Tibet," Geological Bulletin of China, vol. 21, no. 11, pp. 732-734, 2002.

[60] H. Liu, B. Xia, W. Deng, and Y. Zhang, "Study of ${ }^{39} \mathrm{Ar}^{40} \mathrm{Ar}$ and $\mathrm{K}-\mathrm{Ar}$ dating on the high-K volcanic rock from Bamaoqiongzong to Qiangbaqian in the northern Tibet," Mineral and Petrology, vol. 24, no. 1, pp. 71-75, 2004.

[61] Q. Wei, D. Li, G. Wang, and J. Zheng, "Zircon SHRIMP $\mathrm{U}-\mathrm{Pb}$ dating and geochemical characteristics of Chabaoma Formation volcanic rocks in northern Tibetan plateau and its petrogenesis," Acta Petrologica Sinica, vol. 23, no. 11, pp. 2727-2736, 2007.

[62] L. Gao, L. Zeng, J. Liu, and K. Xie, "Early Oligocene Na-rich peraluminous leucogranites in Yadoi gneiss dome, southern Tibet: formation mechanism and tectonic implications," ACTA Petrologica Sinica, vol. 25, no. 9, pp. 2289-2302, 2009.

[63] H. F. Zhang, N. Harris, R. Parrish, L. Zhang, and Z. Zhao, "U-Pb ages of Kude and Sajia leucogranites in Sajia dome from North Himalaya and their geological implications," Chinese Science Bulletin, vol. 49, no. 19, pp. 2087-2092, 2004.

[64] T. Y. Lee and L. A. Lawver, "Cenozoic plate reconstruction of Southeast Asia," Tectonophysics, vol. 251, no. 1-4, pp. 85-138, 1995.

[65] Z. Xu, S. Ji, Z. Cai, L. Zeng, Q. Geng, and H. Cao, "Kinematics and dynamics of the Namche Barwa Syntaxis, eastern Himalaya: constraints from deformation, fabrics and geochronology," Gondwana Research, vol. 21, no. 1, pp. 19-36, 2012.

[66] D. B. Rowley, "Age of initiation of collision between India and Asia: a review of stratigraphic data," Earth and Planetary Science Letters, vol. 145, no. 1-4, pp. 1-13, 1996.

[67] T. Zhu, Y. Yu, C. Jin, B. Zhu, Q. Zhang, and M. Zhou, "Geological survey report and geological map at scale 1:250, 000 of Dogai Corin Quadrangle," Published by Chengdu Institute of Geology and Mineral Resources, China Geological Survey, 2005.

[68] S. Guillot, G. Mahéo, J. de Sigoyer, K. H. Hattori, and A. Pêcher, "Tethyan and Indian subduction viewed from the Himalayan high- to ultrahigh-pressure metamorphic rocks," Tectonophysics, vol. 451, no. 1-4, pp. 225-241, 2008.

[69] J. Besse, V. Courtillot, J. P. Pozzi, M. Westphal, and Y. X. Zhou, "Palaeomagnetic estimates of crustal shortening in the Himalayan thrusts and Zangbo suture," Nature, vol. 311, no. 5987, pp. 621-626, 1984.

[70] C. T. Klootwijk, P. J. Conaghan, and C. M. Powell, "The Himalayan Arc: large-scale continental subduction, oroclinal bending and back-arc spreading," Earth and Planetary Science Letters, vol. 75, no. 2-3, pp. 167-183, 1985.

[71] R. A. Spicer, N. B. W. Harris, M. Widdowson et al., "Constant elevation of southern Tibet over the past 15 million years," Nature, vol. 421, no. 6923, pp. 622-624, 2003.

[72] D. B. Rowley and B. S. Currie, "Palaeo-altimetry of the late Eocene to Miocene Lunpola basin, central Tibet," Nature, vol. 439, no. 7077, pp. 677-681, 2006.

[73] P. M. Blisniuk, B. R. Hacker, J. Glodny et al., "Normal faulting in central Tibet since at least 13.5 Myr ago," Nature, vol. 412, no. 6847, pp. 628-632, 2001.
[74] T. M. Harrison, P. Copeland, W. S. F. Kidd, and O. M. Lovera, "Activation of the Nyainqentanghla shear zone: implications for uplift of the southern Tibetan Plateau," Tectonics, vol. 14, no. 3, pp. 658-676, 1995.

[75] X. Fang, Z. Zhao, J. Li et al., "Magnetostratigraphy of the late Cenozoic Laojunmiao anticline in the northern Qilian Mountains and its implications for the northern Tibetan Plateau uplift," Science in China D, vol. 48, no. 7, pp. 1040-1051, 2005.

[76] J. M. Parés, R. Van der Voo, W. R. Downs, M. Yan, and X. Fang, "Northeastward growth and uplift of the Tibetan Plateau: magnetostratigraphic insights from the Guide Basin," Journal of Geophysical Research-Solid Earth, vol. 108, no. 2017, 11 pages, 2003.

[77] X. Fang, M. Yan, R. Van der Voo et al., "Late Cenozoic deformation and uplift of the NE Tibetan Plateau: evidence from highresolution magnetostratigraphy of the Guide Basin, Qinghai Province, China," Geological Society of America Bulletin, vol. 117, no. 9-10, pp. 1208-1225, 2005.

[78] X. Fang, C. Garzione, R. Van der Voo, J. Li, and M. Fan, "Flexural subsidence by $29 \mathrm{Ma}$ on the NE edge of Tibet from the magnetostratigraphy of Linxia Basin, China," Earth and Planetary Science Letters, vol. 210, no. 3-4, pp. 545-560, 2003. 

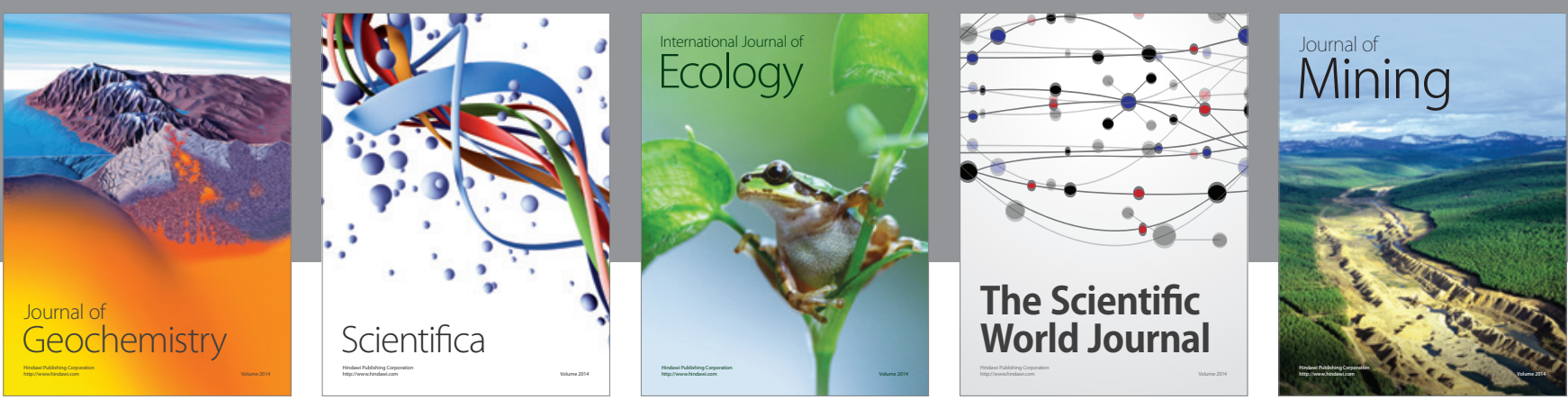

The Scientific World Journal
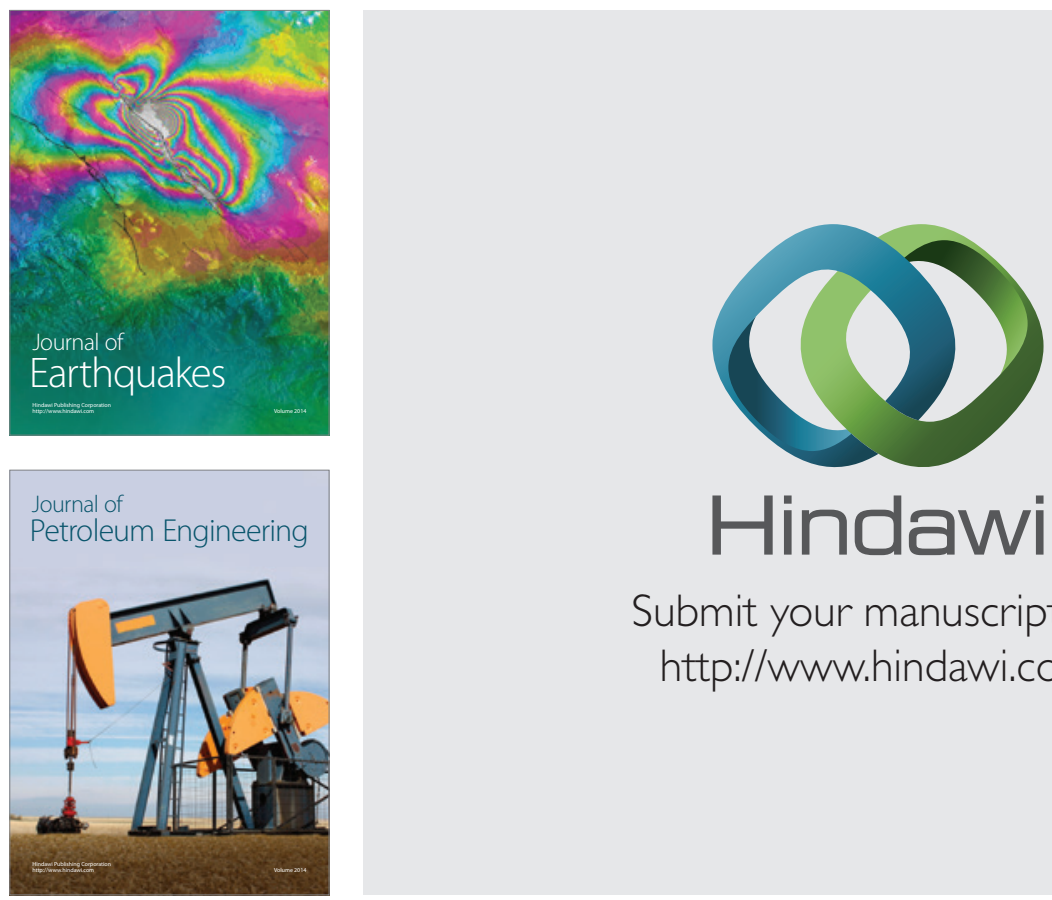

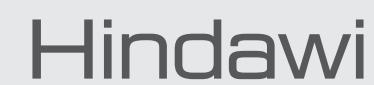

Submit your manuscripts at

http://www.hindawi.com
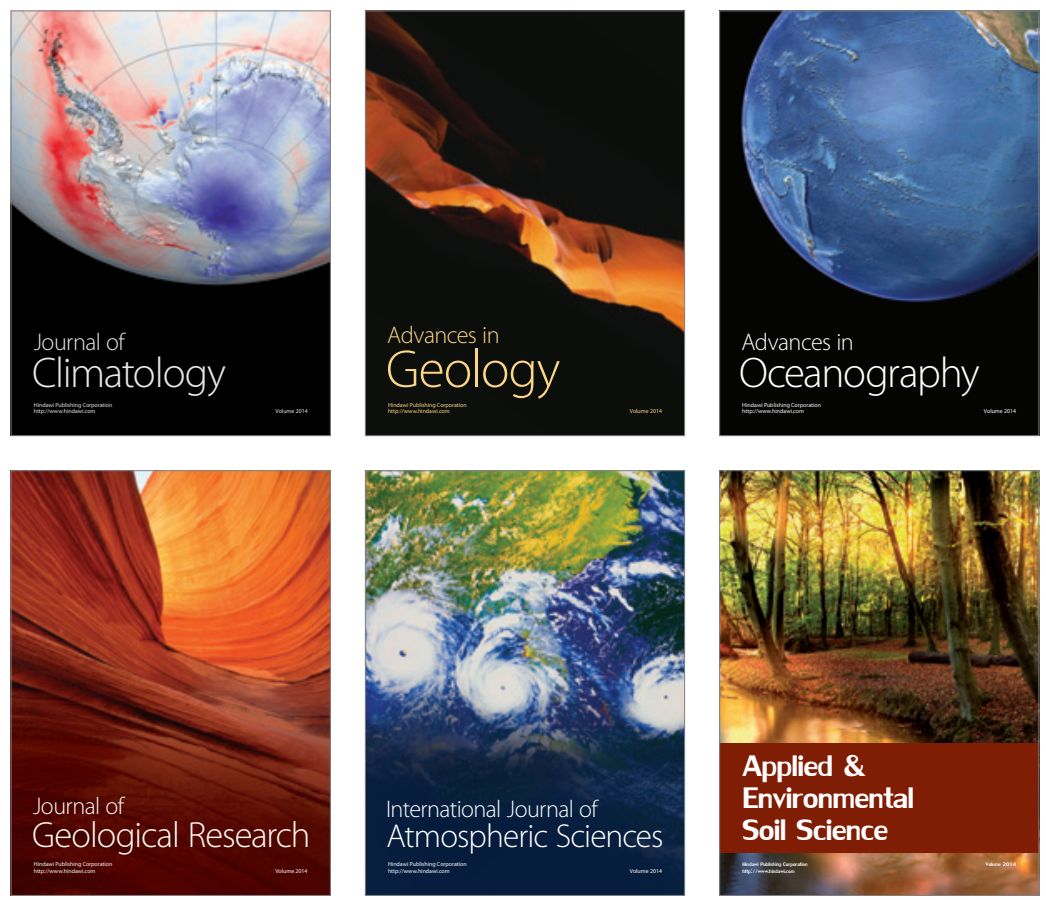
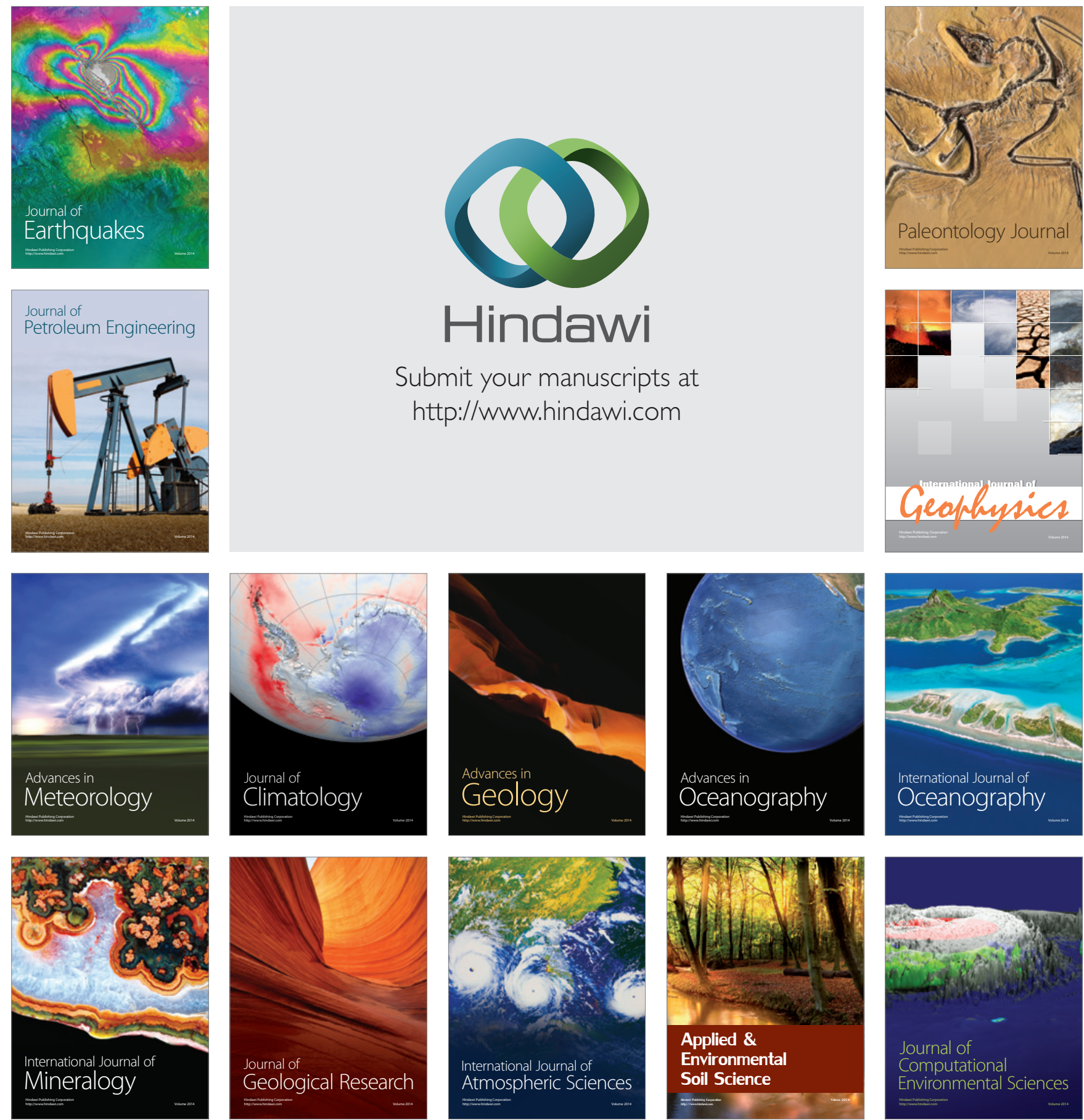